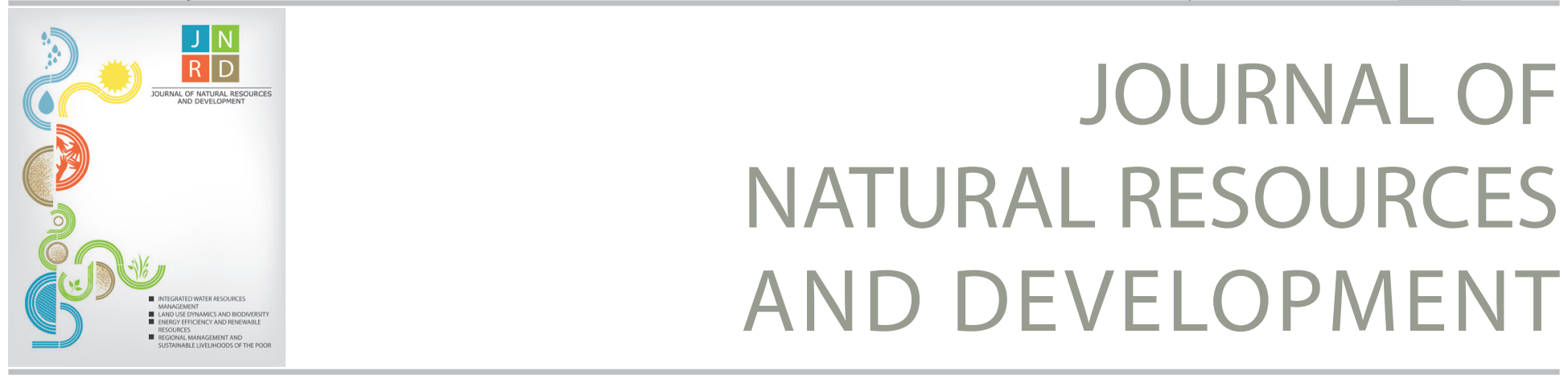

Research note

\title{
Potential for leaching of heavy metals and metalloids from crystalline silicon photovoltaic systems
}

\author{
Seth A. Robinson *a and George A. Meindl b \\ a Department of Biology, University of Florida, Gainesville, FL, USA. \\ b Environmental Studies Program, Binghamton University, Binghamton, NY, USA.
}

* Corresponding author: sethrobinson@ufl.edu

\section{Article history}

Received

$28 / 12 / 2018$

Accepted 07/05/2019

Published 28/05/2019

\section{Keywords}

Photovoltaics

Green energy

Crystalline silicon

Selenium

\section{Abstract}

Photovoltaics (PV) are a rapidly growing technology as global energy sectors shift towards "greener" solutions. Despite the clean energy benefits of solar power, photovoltaic panels and their structural support systems (e.g., cement) often contain several potentially toxic elements used in their construction. Determining whether these elements have the potential to leach into surrounding environments should be a research priority, as panels are already being implemented on a large scale. In this study, we analyzed soil taken from beneath photovoltaic modules to determine if they are being enriched by metals (lead, cadmium, lithium, strontium, nickel, barium, zinc, and copper) and metalloids (selenium) present in panel systems. The soil samples were collected from directly beneath c-Si photovoltaic modules and adjacent fields. Samples were analyzed by inductively coupled plasma optical emission spectrometry (ICP-OES). Selenium, strontium, lithium, nickel, and barium levels measured in soil samples increased significantly in samples closer to PV systems. There were no significant differences in lead or cadmium levels near vs. far from the PV systems. Despite concentration differences for some elements near vs. far from the panel systems, no elements were, on average, present in concentrations that would pose a risk to nearby ecosystems. PV systems thus remain a cleaner alternative to traditional energy sources, such as coal, especially during the operation of these energy production systems.

(C) 2019 This is an open access article under the CC BY-NC-ND license (http://creativecommons.org/licenses/bync-nd/4.0/). 


\section{Introduction}

The demand and innovation of renewable energy systems is increasing as global temperature rises and fossil fuel reserves are exhausted (International Renewable Energy Agency, 2016). Current energy sectors are shifting towards renewable energy, with significant amounts of money ( $\$ 285.9$ billion: 2015) being invested in the development of wind, hydro, and photovoltaic systems (REN21, 2016). Photovoltaic (PV) systems are considered by some to be the most promising of renewable technology as they do not suffer from the same aesthetic and "not in my backyard" controversies as wind power (Good, 2006); nor do they have the same ecological impacts as the infrastructure used for hydroelectric production (Chen, Chen, \& Fath, 2015). In 2015, the annual market of photovoltaic systems increased tenfold over the previous decade (REN21, 2016). This uptick in use has brought increasingly diverse applications of PV technology, including Tesla's solar roof tiles, solar vehicles such as Solar Impulse, and floating PV panels (Harvey, 2016; Vaughan, 2016). Given the potential scale of application of these systems, considering environmental impacts of PV panel installation is important; whether PV systems present any serious ecological risk to surrounding environments during their use is currently unknown.

Photovoltaic panels contain several components known to present health risks to both wildlife and human populations. Metals and metalloids commonly used in panels include cadmium $(\mathrm{Cd})$ and selenium (Se) semiconductors, copper (Cu) wiring, nickel (Ni) and silver $(\mathrm{Ag})$ contacts, tin $(\mathrm{Sn})$ and lead $(\mathrm{Pb})$ soldering, and strontium ( $\mathrm{Sr}$ ) and barium $(\mathrm{Ba})$ doping used to increase panel efficiency (Silicon Valley Toxics Coalition, 2009). Furthermore, structural support components of the PV system, including cement foundations, may also leach hazardous elements into surrounding environments over time (Lu et al., 2016). Lead and Cd, in particular, are contaminants of concern in the solar panel industry due to both their abundance within panels as well as their highly toxic nature (Aman et al., 2015). For example, exposure to $\mathrm{Pb}$ can cause kidney and brain damage as well as mortality in humans (Silicon Valley Toxics Coalition, 2009). Lead is also well documented to reduce reproduction, increase behavior problems, and cause mortality in wildlife (Needleman, 2004; Tranel \& Kimmel, 2009). Cadmium is toxic to the kidneys, blood, prostate, and respiratory system (Silicon Valley Toxics Coalition, 2009). Other metals found within PV materials that are also highly toxic include $\mathrm{Ni}$ and Cd, which are known carcinogens (Needleman, 2004; Silicon Valley Toxics Coalition, 2009); copper (Cu), which can cause kidney and liver damage; Se, which can cause selenosis, a disease of the respiratory system, as well as hair loss and nail brittleness (Silicon Valley Toxics Coalition, 2009); and Sr, which can have negative effects on bone development if consumed in large quantities (Agency for Toxic Substances and Disease Registry, 2004). Despite the known toxicity of these elements, currently there is little information regarding whether or not PV panel systems can leach metals and metalloids into their environments during normal operation.

Photovoltaic environmental life cycle analyses (LCAs) typically address upstream and downstream processes (Corcelli et al., 2018; Stoppato, 2008). A few studies do, however, discuss leaching of metals and metalloids. For example, Alsema, de Wild-Scholten and Fthenakis (2006) and Bohland and Smigielski (2000) both mention minuscule, non-harmful levels of cadmium leaching from panels. Other studies have broken up or ground PV panels into pieces and exposed them to solutions with a lower $\mathrm{pH}$, mimicking acidic rain or waste water (Okkenhaug, Hauge, \& Arp, 2010; Zapf-Gottwick et al., 2015). Specifically, Zapf-Gottwick et al. (2015) found significant amounts of $\mathrm{Pb}$ leached from panels, while Okkenhaug, Hauge, and Arp (2010) found only slightly elevated levels of Cd and Se leached in solution. However, in addition to having equivocal results, these lab studies were not done in the field during normal operation; thus, the question remains if panels leach harmful materials under realistic operating conditions.

The goal of this research is to determine if PV installations are capable of leaching their metal and metalloid components, especially $\mathrm{Pb}$ and $\mathrm{Cd}$, into the environment at levels that are hazardous to both human and ecological health. To achieve this goal, we collected soil samples from beneath c-Si modules and from adjacent, module-free environments, and then compared bioavailable element concentrations between these samples. Accordingly, we asked the following questions: (1) Do soils near PV systems contain higher bioavailable concentrations of metals and metalloids? (2) Are bioavailable concentrations of metals and metalloids near PV systems of human health and ecological concern?.

\section{Methods}

\section{Study Site}

The PV installation sampled is a 750,000-watt installation at State University of New York at Buffalo. Each module consisted of monocrystalline silicon panels with a length of $1.64 \mathrm{~m}$ (64.6 in) and a width of $1.00 \mathrm{~m}$ (39.4 in). Panels were arranged in rows of twelve with a height ranging from one panel to eight. The modules were installed in the winter of 2011 through 2012, and became fully operational in April of 2012.

\section{Sample Methods}

Soil samples were collected in June of 2017. Starting at $100 \mathrm{ft}$ from the edge of the outside modules, samples of about $500 \mathrm{~g}$ were collected every $15 \mathrm{ft}$ following a $250 \mathrm{ft}$ line parallel to a section of the PV modules. Working inwards to minimize possible contamination, samples were taken again at $45 \mathrm{ft}$ and again at one final transect through the middle of the PV modules. Each of the five transects $(100 \mathrm{ft}, 45 \mathrm{ft}, 0 \mathrm{ft})$ had a total of fifteen samples taken for a total of 45 samples collected.

$200 \mathrm{~g}$ of each sample was then transferred to brown paper bags and dried for 48 hours at $65^{\circ} \mathrm{C}$. Samples were passed through a $2 \mathrm{~mm}$ sieve to remove large particulate matter. Samples were ground for 1 min using an agate mortar and pestle. The ground samples were then passed through a $0.125 \mathrm{~mm}$ sieve, with $2.5 \mathrm{mg}$ of each being transferred to a $50 \mathrm{~mL}$ polypropylene centrifuge tube. 


\section{Metal Extraction}

For the extraction process, we followed TCLP Method 1311 set forth by the U.S. Environmental Protection Agency (1992). Following the above protocol, because the $\mathrm{pH}$ of our soil solutions was $>5$, we used TCLP reagent number 2 U.S. Environmental Protection Agency (1992). Following the TCLP reagent number $2,5.7 \mathrm{~mL}$ of Glacial Acetic Acid $\left(\mathrm{CH}_{3} \mathrm{CO}_{2} \mathrm{H}\right)$ was diluted with $1 \mathrm{~L}$ of nanopure water. The final $\mathrm{pH}$ of the solution was 2.86. Each $50 \mathrm{~mL}$ tube with $2.5 \mathrm{~g}$ of soil received 50 $\mathrm{mL}$ of the diluted $\mathrm{CH}_{3} \mathrm{CO}_{2} \mathrm{H}$ (20x the sample mass). The tubes were then rotated for 18 hours at $30 \mathrm{rpm}$. Four blank tubes filled with $50 \mathrm{~mL}$ of nanopure water accompanied each round of samples and were processed as controls. Acetic acid extraction is often used for determining leachable (i.e., bioavailable) fractions of metals in soil (Dean, 2010), and thus is appropriate for use in studies like ours that are interested in risk assessment to local ecosystems.

\section{Sample Analysis}

After rotation, samples sat overnight and then were decanted into 15 $\mathrm{mL}$ polypropylene centrifuge tubes using a pipette. They were then analyzed for $\mathrm{Pb}, \mathrm{Cd}$, lithium (Li), $\mathrm{Sr}, \mathrm{Ni}, \mathrm{Ba}$, zinc ( $\mathrm{Zn}), \mathrm{Cu}$, and Se using inductively coupled plasma optical emission spectrometry (ICP-OES), with results being reported in parts per million (ppm). We used ANOVA (SPSS 24; IBM) to compare element concentrations across our three sample transects.

\section{Results}

We found no difference in $\mathrm{Cd}$ concentrations $(\mathrm{F} 2,27=0.20, \mathrm{p}=$ 0.82 ; Figure 1) or $\mathrm{Pb}$ concentrations ( $\mathrm{F} 2,27=2.08, \mathrm{p}=0.14$; Figure 1) along our distance gradient away from the panels. Selenium levels increased by $97 \%$ from $100 \mathrm{ft}$ to $0 \mathrm{ft}$ in proximity to the PV panels $(F 2,27=9.96, p<0.01$; Figure 1$)$, Li increased by $386 \%(F 2,27=$ 4.74, $p=0.02$; Figure 1), Sr increased by $86 \%(F 2,27=4.89, p=0.02$; Figure 1), Ni increased by $37 \%(F 2,27=7.18, p<0.01$; Figure 1), and Ba increased by $61 \%(F 2,27=5.25, \mathrm{p}<0.01$; Figure 1). Zinc and $\mathrm{Cu}$ decreased significantly from the 100 -foot mark to under the panels. Copper decreased by $1277 \%(F 2,27=18.23$, $p<0.01$; Figure 1$)$ and Zn decreased by $195 \%(F 2,27=21.32, p<0.01$; Figure 1$)$.

\section{Discussion}

In this study, we found that soil enrichment of $\mathrm{Pb}$ and $\mathrm{Cd}$ did not occur with closer proximity to PV systems. The values recorded for $\mathrm{Se}, \mathrm{Li}, \mathrm{Sr}, \mathrm{Ni}$, and $\mathrm{Ba}$ show a significant increase in concentration in soil closer to PV systems, while Zn and Cu increase significantly away from the systems. Below, we compare our results to soil concentration risk thresholds established by the Environmental Protection Agency's (USA) Ecological Soil Screening Level (Eco-SSL) risk assessment (U.S. Environmental Protection Agency, 2018), which is a conservative soil screening process that assumes soil metals are present in bioavailable form. In addition, we discuss the potential for leaching of potentially toxic elements from operational PV systems.
Several elements tested were either not variable across our distance gradient or were present in low concentrations that are not of immediate environmental concern. While studies suggest that $\mathrm{Pb}$ and $\mathrm{Cd}$ are the most common leachates from PVs (Okkenhaug, Hauge, \& Arp, 2010; Zapf-Gottwick et al., 2015), Pb and Cd measured in this study were not elevated in soils near PV systems and were far below levels considered to be an imminent or future danger to environmental health [wildlife risk threshold for $\mathrm{Pb}: 11 \mu \mathrm{g}-1 \mathrm{~g}$; for $\mathrm{Cd}$ : $0.36 \mu-1 \mathrm{~g}$ (U.S. Environmental Protection Agency, 2018)]. For intact PV panels, leaching of these elements is unlikely to occur, thus most of the concern for contamination of $\mathrm{Pb}$ and $\mathrm{Cd}$ from solar panels relates to panels disposed in landfills that degrade over time, and become exposed to water (Zapf-Gottwick et al., 2015). However, it is possible under operating conditions that PV panels can leach toxic elements if water penetrates into the modules through damaged areas, such as cracks in the module glass or through defective laminations. Thus, it appears that the modules studied here are intact and do not provide a mechanism for the leaching of internal $\mathrm{Pb}$ and $\mathrm{Cd}$. Although $\mathrm{Li}, \mathrm{Ba}$, $\mathrm{Ni}$, and $\mathrm{Sr}$ were recorded as significantly higher in soils beneath PV panels, the amounts recorded for these elements were all well below the soil screening values defined by the EPA and others (Shahzad et al., 2016; U.S. Environmental Protection Agency, 2018; 40 C.F.R. § 261.24, 1996); thus, the c-Si panels do not seem to pose a risk of contamination of these elements during normal operation.

Selenium was observed to be significantly higher in soils closer to our study PV panels. In contrast to the other recorded elements, the levels observed may be of concern. The Eco-SSL risk threshold soil values for Se are $0.52 \mu \mathrm{g}$ - $1 \mathrm{~g}$ for plants, and $0.63 \mu \mathrm{g}-1 \mathrm{~g}$ for mammals (U.S. Environmental Protection Agency, 2018). In our study, the average Se concentration measured directly by the PV systems was $0.48 \mu \mathrm{g}-1$ $\mathrm{g}$, while the highest level of Se observed near the PV systems was $0.57 \mu \mathrm{g}-1 \mathrm{~g}$. Thus, using the conservative risk thresholds established by the EPA's Eco-SSL, Se concentrations near the PV systems are approaching a level of environmental concern for local plants and other wildlife. However, over time, even low concentrations of certain elements can become problematic due to accumulation in soil and nearby organisms. Bioaccumulation of Se occurs in both aquatic and terrestrial ecosystems (Mann, Vijver, \& Peijnenburg, 2011). A study done in association with the US Department of Agriculture (Bañuelos et al., 2002) addressing phytoremediation of Se found that the Se accumulated could be transferred to animals that consumed the plants. Likewise, deleterious effects of predators could occur if they were to consume these animals with elevated Se in their tissue (Mann, Vijver, \& Peijnenburg, 2011). Environmental regulators have noted the potential of Se to integrate into trophic systems, and have thus set acceptable levels extremely low when compared to other metals and metalloids (Ministerie van Volkshuisvesting, 2000). Future studies examining leaching of elements from PV systems should consider indirect effects of these elements on ecosystems, including bioaccumulation by plants and animals near PV systems. C-Si panels are not known to contain appreciable amounts of Se, thus the source of Se observed in our study is unclear. In a similar study that examined both copper indium selenide (CIS) panels and cadmium telluride (CdTe) panels, Se in soil near CIS panels on roofs was found to be elevated by $0.3 \mu \mathrm{g}$ per $\mathrm{g}$ when compared to surrounding soil. 


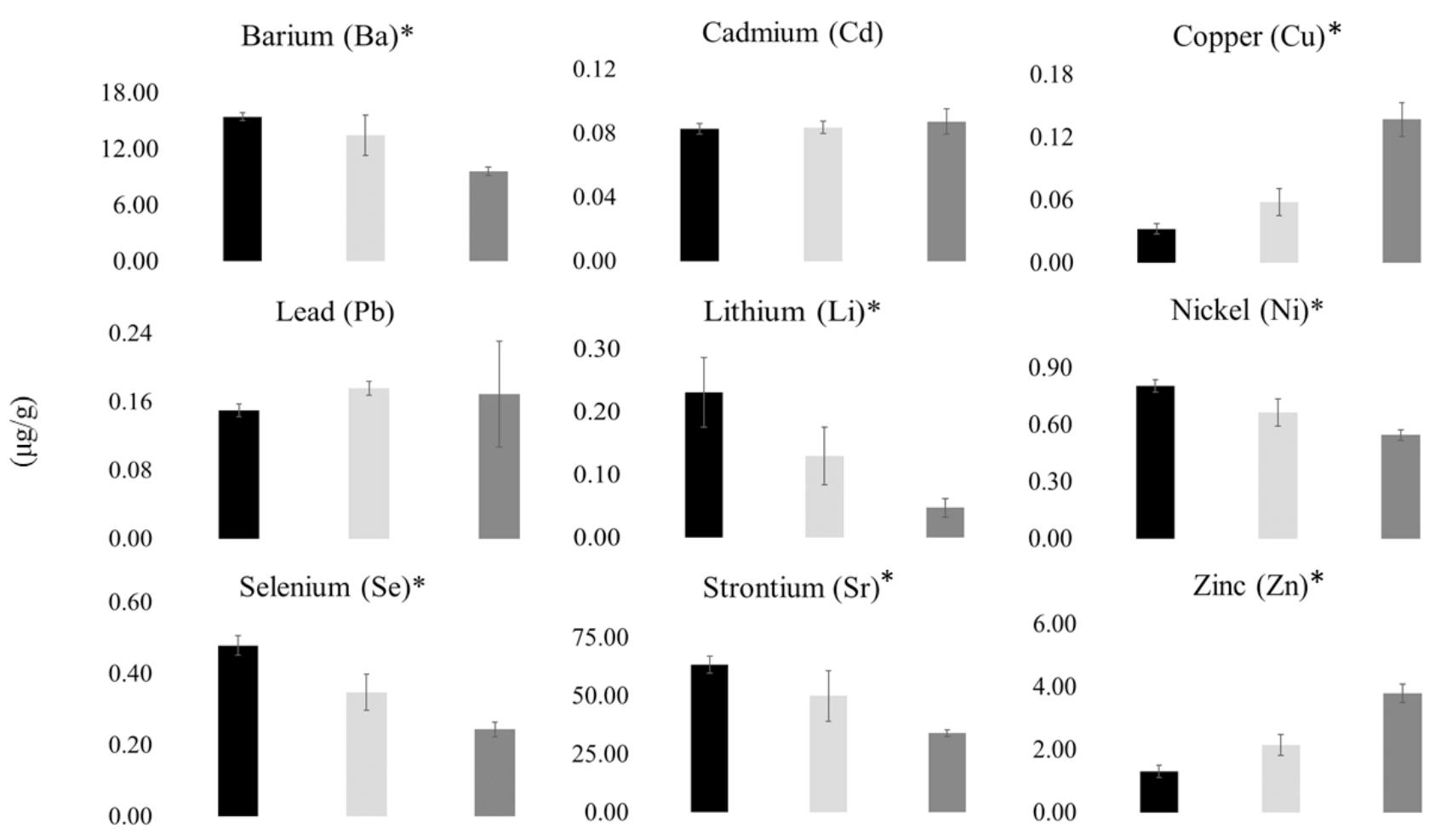

Distance from PV Modules

0 Feet

45 Feet

100 Feet

Figure 1: . Soil concentrations of barium (Ba), cadmium (Cd), copper (Cu), lithium (Li), nickel (Ni), lead (Pb), selenium (Se), strontium (Sr), and zinc $(\mathrm{Zn})$ at varying distances from the photovoltaic panels. Asterisks indicate significant differences among groups.

Conversely, Se levels in soil near CdTe were not elevated (Steinberger, 1998). C-Si panels do not have Se concentrations as high as amounts reported in CIGS (Copper Indium Gallium Selenide) panels (Silicon Valley Toxics Coalition, 2009). Likewise, Sr, which is a new material to the PV panel industry, does not have an integral position to the manufacturing of PVs. The most common application currently for $\mathrm{Sr}$ in PV cells is to increase the efficiency of perovskite panels (Shai et al., 2017; Wu et al., 2018). However, c-Si panels, like those studied here, generally incorporate perovskite technology without $\mathrm{Sr}(\mathrm{Ba}$, Liu, \& Shen, 2018).

Therefore, the source of metals and metalloids documented under the PV system in this study may be from system components other than the panels themselves. Terrestrial PV modules are constructed of c-Si panels mounted on aluminum frames, which are secured into the ground using cement. It is quite possible that the elevated levels of Se and other elements studied here are a result of the cement used in construction. An impact assessment study conducted on a quarry and cement plant in California found discharge from the plant contained levels of Se well over $50 \mathrm{mg}^{-1} \mathrm{~L}$. The source of this was identified as the limestone mined for use in cement (Nalbandian, 2012). Furthermore, in addition to metals being introduced in raw materials (e.g., Se and Sr in limestone), the production clinker granules within cement are often produced using coal fly ash additives, which can introduce metals such as $\mathrm{Ba}, \mathrm{Cr}$, and $\mathrm{Ni}$ (Cipurkovic et al., 2014). These metals may later leach from the cement into the environment following exposure to water under realistic environmental conditions (Lu et al., 2016). Thus, our reported increase of bioavailable metals and metalloids beneath the intact panels should prompt further investigation regarding PV system-wide pollution.

Overall, PV systems should still be considered a clean energy relative to traditional sources. In comparison, the amount of $\mathrm{Pb}$ in fly ash

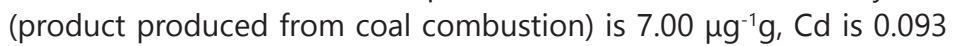
$\mu \mathrm{g}^{-1} \mathrm{~g}$ and $\mathrm{Se}$ is $2.15 \mu \mathrm{g}^{-1} \mathrm{~g}$ (Nalbandian, 2012). Although most of this contaminated fly ash may not affect the immediate vicinity, it is commonly disposed of in landfills and as a soil amendment in agriculture (Haynes, 2009). Despite toxic metal components, the PV panel industry is growing at such a fast pace that innovation should quickly phase out the use of harmful substances. 
Examples of this include use of materials other than $\mathrm{Pb}$ for soldering as well as using organic materials as semiconductors instead of metals and metalloids (Kippelen, \& Brédas, 2009). However, until these advancements occur industry-wide (e.g., organic materials are not yet commercially used as semiconductors due to low efficiency and stability; (Burlingame et al., 2018)), further studies are needed to determine the extent of leaching that occurs using current PV technology. While TLCP analyses of solar panels are common place for waste characterization [e.g., Okkenhaug, Hauge, \& Arp, 2010), there is a paucity of studies that assess potential for leaching of toxic elements from PV systems during active operation.

We conclude that while no elements were, on average, above soil screening thresholds established by the EPA's Eco-SSL, further studies are needed to determine the impacts of PV system installation and operation on terrestrial ecosystems. PV systems, however, remain a cleaner alternative to traditional energy sources, such as coal, especially during the operation of these energy production systems.

\section{Acknowledgments and Financial support}

This project was funded in part by The Ronald E. McNair Postbaccalaureate Achievement Program at Binghamton University. We thank our colleagues at Binghamton University including Jonathan Schmitkons, John Titus, Joseph Graney, and David Collins. A special thanks to Alona Armstrong of Lancaster University for her role in inspiring this project.

\section{References}

Agency for Toxic Substances and Disease Registry. (2004). Toxicological profile for Strontium. Atlanta, GA: U.S. Department of Health and Human Services, Public Health Service.

Alsema, E., de Wild-Scholten, M., \& Fthenakis, V. (2006, Sep 4-8) Environmental impacts of PV electrical generation- a critical comparison of energy supply options," Paper presented at the 21st European Photovoltaic Solar Energy Conference, Dresden, Germany.

Aman, M. M., Solangi, K. H., Hossain, M. S., Badarudin, A., Jasmon, G. B., Mokhlis, H., Baker, A. H. A., \& Kazi, S. N. (2015). A review of safety, health and environmental (SHE) issues of solar energy system. Renewable and Sustainable Energy Reviews, 41, 1190-1204. doi: https://doi.org/10.1016/j.rser.2014.08.086

Ba, L., Liu, H., \& Shen, W. (2018). Perovskite/c-Si tandem solar cells with realistic inverted architecture: Achieving high efficiency by optical optimization. Progress in Photovoltaics: Research and Applications, 26(11), 924-933. doi: https://doi.org/10.1002/pip.3037

Bañuelos, G. S., Vickerman, D. B., Trumble, J. T., Shannon, M. C., Davis, C. D., Finley, J. W., \& Mayland, H. F. (2002). Biotransfer Possibilities of Selenium from Plants Used in Phytoremediation. International Journal of Phytoremediation, 4(4), 315-329. doi: https://doi.org/10.1080/15226510208500090

Bohland J. R., \& Smigielski, K. (2000, Sep 15-22). First Solar's CdTe module manufacturing experience; environmental, health and safety results. Paper presented at the Conference Record of the Twenty-Eighth IEEE Photovoltaic Specialists Conference, Anchorage, AK, USA.

Burlingame, Q., Coburn, C., Che, X., Panda, A., Qu, Y., \& Forrest, S. R. (2018). Centimetrescale electron diffusion in photoactive organic heterostructures. Nature, 554, 77-80. doi: https://doi.org/10.1038/nature25148

Cipurkovic, A., Trumic, I., Hodžic, Z., Selimbašic, V., \& Djozic, A. (2014). Distribution of heavy metals in Portland cement production process. Advances in Applied Science Research, 5(6), 252-259.

Corcelli, F., Ripa, M., Leccisi, E., Cigolotti, V., Fiandra, V., Graditi, G., Sannino, L., Tammaro, M., $\&$ Ulgiati, S. (2018). Sustainable urban electricity supply chain - Indicators of material recovery and energy savings from crystalline silicon photovoltaic panels end-of-life. Ecological Indicators, 94, 37-51. doi: https://doi.org/10.1016/j.ecolind.2016.03.028

Chen, S., Chen, B., \& Fath, B. D. (2015). Assessing the cumulative environmental impact of hydropower construction on river systems based on energy network model. Renewable and Sustainable Energy Reviews, 42, 78-92. doi: https://doi.org/10.1016/j. rser.2014.10.017

Dean, J. R. (2010). Heavy metal bioavailability and bioaccessibility in soil. In: Cummings S. (eds) Bioremediation. Methods in Molecular Biology (Methods and Protocols), vol 599, 15-36. Humana Press. doi: https://doi.org/10.1007/978-1-60761-439-5_2 Good, J. (2006). The aesthetics of wind energy. Human Ecology Review, 13(1), 76-89.

Harvey, F. (2016, Feb 29). World's biggest floating solar farm powers up outside London. The Guardian. Retrieved from www.theguardian.com/environment/2016/feb/29/ worlds-biggest-floating-solar-farm-power-up-outside-london

Haynes, R. J. (2009). Reclamation and revegetation of fly ash disposal sites - Challenges and research needs. Journal of Environmental Management, 90(1), 43-53. doi: https:// doi.org/10.1016/j.jenvman.2008.07.003

International Renewable Energy Agency. (2016). Renewable energy and jobs - annual review 2016. Retrieved from https://www.irena.org/publications/2016/May/ Renewable-Energy-and-Jobs--Annual-Review-2016

Kippelen, B., \& Brédas, J.-L. (2009). Organic photovoltaics. Energy \& Environmental Science, 2(3), 251. doi: https://doi.org/10.1039/b812502n

Lu, H., Wei, F., Tang, J., \& Giesy, J. P. (2016). Leaching of metals from cement under simulated environmental conditions. Journal of Environmental Management, 169, 319-327. doi: https://doi.org/10.1016/j.jenvman.2015.12.008

Mann, R. M., Vijver, M. G., \& Peijnenburg, W. J. G. M. (2011). Metals and metalloids in terrestrial systems: Bioaccumulation, biomagnification and subsequent adverse effects. In Sánchez-Bayo, F., van den Brink, P. J., \& Mann, R. M. (Eds), Ecological Impacts of Toxic Chemicals (43-62). Sydney. doi: https://doi.org/10.2174/9781608051212111 01010043

Ministerie van Volkshuisvesting, Ruimtelijke Ordening en Milieubeheer. (2000). Dutch Target and Intervention Values.

Nalbandian, H. (2012). Trace element emissions from coal. IEA Clean Coal Centre Retrieved from https://www.usea.org/sites/default/files/092012_Trace\%20 element\%20emissions\%20from\%20coal_ccc203.pdf

Needleman, H. (2004). Lead poisoning. Annual Review of Medicine, 55(1), 209-222. doi: https://doi.org/10.1146/annurev.med.55.091902.103653

Okkenhaug, G., Hauge, A., \& Arp, H. (2010). Environmental risks regarding the use and final disposal of CdTe PV modules. Norwegian Geotechnical Institute (NGI) Report 20092155-00-1-R. Norway.

REN21. (2016). Renewables 2016 Global Status Report. Retrieved from http://www.ren21. net/wp-content/uploads/2016/05/GSR_2016_Full_Report_lowres.pdf

Shahzad, B., Mughal, M. N., Tanveer, M., Gupta, D., \& Abbas, G. (2016). Is lithium biologically an important or toxic element to living organisms? An overview. Environmental Science and Pollution Research, 24(1), 103-115. doi: https://doi.org/10.1007/s11356016-7898-0

Shai, X., Zuo, L., Sun, P., Liao, P., Huang, W., Yao, E., Li, H., Liu, S., Shen, Y., Yang, Y., \& Wang, M. (2017). Efficient planar perovskite solar cells using halide Sr-substituted $\mathrm{Pb}$ perovskite. Nano Energy, 36, 213-222. doi: https://doi.org/10.1016/j.nanoen.2017.04.047

Silicon Valley Toxics Coalition. (2009, Jan 14). Towards a just and sustainable solar industry. Silicon Valley Toxics Coalition. Retrieved from 
http://svtc.org/wp-content/uploads/Silicon_Valley_Toxics_Coalition_-_Toward_a_Just_ and_Sust.pdf

Steinberger, H. (1998). Health, safety and environmental risks from the operation of CdTe and CIS thin-film modules. Progress in Photovoltaics: Research and Applications, 6, 99$103,1998$.

Stoppato, A. (2008). Life cycle assessment of photovoltaic electricity generation. Energy, 33(2), 224-232. doi: https://doi.org/10.1016/j.energy.2007.11.012

Tranel, M., \& Kimmel, R. (2009). Impacts of lead ammunition on wildlife, the environment, and human health - a literature review and implications for Minnesota. Ingestion of Lead from Spent Ammunition: Implications for Wildlife and Humans. doi https://doi. org/10.4080/ilsa.2009.0307

U.S. Environmental Protection Agency. (1992). Method 1311: Toxicity characteristic leaching procedure. Test methods for evaluating solid waste, Physical/Chemical Methods.

U.S. Environmental Protection Agency. (2018, Dec 20). Ecological soil screening level. Retrieved from https://www.epa.gov/chemical-research/ecological-soil-screening- level

Vaughan, A. (2016, Jan 27). Japan begins work on 'world's largest' floating solar farm. The Guardian. Retrieved from www.theguardian.com/environment/2016/jan/27/japanbegins-work-on-worlds-largest-floating-solar-farm

Vodyanitskii, Y. N. (2016). Standards for the contents of heavy metals in soils of some states. Annals of Agrarian Science, 14(3), 257-263. doi: https://doi.org/10.1016/j. aasci.2016.08.011

Wu, M.-C., Chen, W.-C., Chan, S.-H., \& Su, W.-F. (2018). The effect of strontium and barium doping on perovskite-structured energy materials for photovoltaic applications. Applied Surface Science, 429, 9-15. doi: https://doi.org/10.1016/j.apsusc.2017.08.131

Zapf-Gottwick, R., Koch, M., Fischer, K., Schwerdt, F., Hamann, L., Kranert, M., Metzger, J., \& Werner, J. (2015). Leaching hazardous substances out of photovoltaic modules. International Journal of Advanced Applied Physics Research, 2(2), 7-14. doi: https://doi. org/10.15379/2408-977x.2015.02.02.2

40 C.F.R. § 261.24. United States Environmental Protection Agency. 1996. 